\title{
Erratum to: Role of Dendritic Cells in Atopic Dermatitis: An Update
}

Thomas Bieber • Natalija Novak • Nadine Herrmann • Susanne Koch

Published online: 8 February 2011

(C) Springer Science+Business Media, LLC 2011

Erratum to: Clinic Rev Allerg Immunol

DOI 10.1007/s12016-010-8224-0

In the original version of this article, one of the authors' names contains a typographical error. The correct spelling is Nadine Herrmann.

The online version of the original article can be found at http://dx.doi. org/10.1007/s12016-010-8224-0.

T. Bieber $(\bowtie) \cdot$ N. Novak $\cdot$ N. Herrmann $\cdot$ S. Koch

Department of Dermatology and Allergy, University of Bonn,

Medical Center,

Sigmund-Freud-Str. 25,

53127 Bonn, Germany

e-mail: Thomas.Bieber@ukb.uni-bonn.de 